\title{
GLOSSARY OF KEY PERSONSAND TERMS
}

Alo Chöndze

amban

Big Three Monastic

Seats

Chamdo

chandzö

Che Jigme

Chömpel Thubden

Coocoola

dayan

Deng Xiaoping a leader of the second People's Association

Imperial commissioners sent by the Qing dynasty to Tibet

see "Three Monastic Seats"

the town in Eastern Tibet that was the headquarters of the governor of Kham, or Eastern Tibet, and the target of the PLA's invasion in $195^{\circ}$

a manager working for a monastery, labrang, or aristocratic family

one of the two top officials in the Panchen Lama's Administrative Council

one of the four heads (trunyichemmo) of the

Ecclesiastic Office; a major spokesman in $195^{1}$ for

the Dalai Lama's returning to Lhasa rather than going into exile

an English-speaking Sikkimese princess married to a Tibetan aristocrat from the Phünkang family. She was a frequent source of information for the United States.

a Chinese silver coin from the old society used by the PLA in Tibet in the $195^{\circ}$ s, because Tibetans did not accept Chinese paper currency

one of the two main leaders of the Southwest Bureau during $195^{0}-5^{2}$. In 1953 he moved to Beijing to 
depön

divine lottery (senril)

dobdo

Dombor (Kyenrab Wangchuk)

dotse

dzasa

Ecclesiastic Office (Yigtsang)

Fan Ming

geshe

Guomindang (GMD)

gyagpön

Gyalo Thondup serve as the secretary-general of the Central Committee.

commander or general in charge of a regiment in the traditional Tibetan army. If a regiment had only five hundred troops, there was usually only one depön, but if there were a thousand troops, there were usually two.

a type of divination frequently used by the Tibetan government to make major decisions. The lottery was based on two or more alternative answers being written on paper and rolled into dough balls of exactly the same size and weight. These were placed in a bowl and shaken before the statue or icon of a deity until one ball rolled out, which was the one believed to contain the answer chosen by the deity. a kind of deviant fighting/punk monk found in many larger monasteries

an acting Kashag minister in the $195^{\mathrm{os}}$

a Tibetan unit of currency that was equal to fifty ngüsang

(1) a high rank in the Tibetan government; (2) a title of some Labrang managers, such as Kundeling Labrang

the highest office in the monk official side of the Tibetan government. It was headed by four officials called trunyichemmo.

a senior Northwest Bureau cadre who was the representative to the Panchen Lama and a major official in the Tibet Work Committee in Lhasa

an advanced degree earned by scholar monks the Nationalist Party that ruled China until the CCP defeated it and established the PRC in October 1949. Prior to the language reforms of the People's Republic of China, it was normally romanized as "Kuomintang" (KMT).

a noncommissioned officer in charge of a unit of one hundred in the traditional Tibetan army

the second oldest brother of the Dalai Lama and one of the leaders of Jenkhentsisum 
Jenkhentsisum

jigyab khembo

kadrung

kalön

kandrön

Kashag

khe

Kheme Dzasa (Sonam Wangdü)

khenjung

labrang the informal name of the anti-Chinese exile group in India. The term is an acronym of the titles of its three leaders, Gyalo Thondup, Tsipön Shakabpa, and Khenjung Lobsang Gyentsen-literally, jen (older brother), khen (khenjung), tsi (tsipön), and sum (word for the number three).

the highest monk official in the government. His responsibilities included oversight of the Dalai Lama's personal attendants and private treasury (tib. dzöbu). The jigyab khembo was also entitled to sit with the Kashag but typically went there only on special occasions, for example, if the Dalai Lama had something to tell the Kashag. Between $195^{2}$ and $195^{6}$, the jigyab khembo was the Dalai Lama's brother Lobsang Samden.

important administrative aides to the Kashag ministers. There were usually two of these, both aristocratic lay officials. Their job was to assist the ministers in any way needed, but their usual work involved writing whatever drafts, letters, documents, orders, or recommendations the Kashag sent to the Dalai Lama and other offices and the edicts the Kashag sent to counties. By custom, the seal of the Kashag could be applied only by the two kadrung, even if the ministers were present.

the title for a Kashag minister

administrative aides to the Kashag. There were usually three of these, all aristocratic lay officials. They were in charge of petitions to the Kashag. the highest office in the Tibetan government a basic Tibetan measure of volume. One khe of barley weighed about thirty-one pounds.

one of the commanders-in-chief of the Tibetan army. He was a part of the Tibetan delegation that went to Beijing and signed the Seventeen-Point Agreement. He was also the uncle (father's brother) of Surkhang, one of the Kashag ministers.

a rank and title for monk officials that was equal to fourth-rank (rimshi) officials in the lay side of the traditional government bureaucracy

(1) the common name of the Panchen Lama's 
Le Yuhong

Lhalu

li

Li Jingquan

Ling Rimpoche

Liu Bocheng

Liu Geping

Liu Shaoqi

Liushar (Thubden Tharba)

Li Weihan

Lobsang Samden

Lobsang Tashi

lord chamberlain

Lukhangwa

mendredensum government (sometimes referred to as Tashilhunpo

Labrang); (2) name of a large Gelugpa monastery in Gansu; (3) the corporate property-holding entity of any incarnate lama

an important cadre who came with Zhang Jingwu in $195^{1}$. He worked in the Tibet Work Committee in Lhasa and maintained a valuable diary. (Also known as Alo Budrang.)

Kashag minister and governor of Chamdo until replaced by Ngabö in the fall of $195^{\circ}$

a Chinese measure of distance equal to about half of a kilometer

the first party secretary of Sichuan Province

the senior tutor of the Dalai Lama

the commander of the Second Field Army and a major Southwest Bureau official

an ethnic Hui (Muslim) who was deputy director of the United Front Work Department and the State Nationalities Commission in Beijing one of the top leaders in the CCP in the $195^{\text {os. He }}$ served, among many positions, as president of the People's Republic of China.

the codirector of the Tibetan government's Foreign Office and one of the two government liaison officers assigned to the Chinese

a key official in Beijing dealing with minority nationalities. He was the director of the United Front Work Department and the State Nationalities Commission.

the third oldest brother of the Dalai Lama. He was a monk official in the Tibetan government. In early $195^{2}$, he was appointed the jigyab khembo.

the monk official who was one of the two sitsab during $195^{0}-5^{2}$

a monk official in the Dalai Lama's court who was in charge of access to the Dalai Lama

the lay aristocratic official who was one of the two sitsab during $195^{\circ}-5^{2}$

a type of religious offering given to lamas that represents the body (via a statue), the speech (via a text/ scripture), and the mind (via a stupa) 
miser

Mönlam

Mönlam Chemmo

Mullik

Mu Shengzhong

Namseling

Ngabö (Ngawang Jigme)

ngüsang

Peng Dehuai

Phala

Phüntso Tashi

Phüntso Wangye

Phünwang

Ragasha (Phüntso Rabgye)

Ramba (Thubden Güngyen)

Reting a term that can refer to a serf or a bound subject as well as a citizen, depending on the context. For example, "miser of a lord" connotes the serfs of that lord, whereas "miser of Tibet" connotes citizens of Tibet.

in this book, a short form of Mönlam Chemmo

the Great Prayer Festival held in Lhasa at the start of the first Tibetan lunar month

the head of Indian Intelligence Bureau for most of the $195^{\circ}$

one of the senior cadre from the Northwest Bureau who came with Fan Ming to Lhasa

an anti-Chinese nationalist aristocratic official who was one of the four heads of the Revenue Office (Tsigang)

the Tibetan governor-general at the time of the Chinese invasion of $195^{\circ}$. He was the head of the Tibetan negotiating team in Beijing for the SeventeenPoint Agreement talks and then returned to Tibet in September $195^{1}$ and resumed his activities as one of the Kashag ministers. The leading progressive in the Tibetan government.

a Tibetan unit of currency, fifty of which equaled one dotse

the first secretary of the Northwest Bureau and the commander of the First Field Army. He also commanded the PLA troops in the Korean War.

a powerful monk official from an important aristocratic family. During the period of this history, he was the lord chamberlain.

See "Takla (Phüntso Tashi)"

a Tibetan cadre in the Southwest Bureau who was the only Tibetan on the Tibet Work Committee in Lhasa abbreviation of "Phüntso Wangye" member of the Kashag in the $195^{\text {os }}$

the elder member of the Kashag, who was a monk official

the regent from 1933 to 1941 . He sought unsuccessfully to return to power in $1944-45$ and then plotted 
rimpoche

rupön

sang

sawangchemmo

senril

Shakabpa (Wangchuk Denden)

Shasur (aka Shenkawa) (Gyurme Dorje)

shondrön sitsab

Surjong Kashag

Surkhang (Wangchen Gelek)

Tan Guansan

Takla (Phüntso Tashi)

Taktra (Rimpoche) Taktse Rimpoche

Three Monastic Seats a coup against the sitting regent, Taktra. He was arrested and imprisoned, where he mysteriously died. Most believe he was poisoned.

title for an incarnate lama

a military officer in the traditional Tibetan army just under a depön; usually in charge of half of a regiment same as ngüsang

term of address for Kashag ministers

see "divine lottery (senril)"

the key Tibetan official dealing with the United States and India in $195^{0-5} 5^{1}$; later a leader of Jenkhentsisum, the anti-Chinese resistance organization in India

one of the acting Kashag ministers in the $195^{\mathrm{os}}$

monk official aides in the secretariat of the regent the two officials appointed in $195^{\circ}$ to head the government while the Dalai Lama was in Yadong.

the special three-minister "little Kashag" office that had the authority to streamline implementation of the Seventeen-Point Agreement

one of the Kashag ministers in the $195^{\circ}$

a Southwest Bureau official who was one of the leading officials in the Tibet Work Committee in Lhasa

a Tibetan from Amdo who married the Dalai

Lama's sister and became an official of the Tibetan government. He was one of the few officials who knew Chinese.

the regent of Tibet from $194^{1}$ to $195^{\circ}$

the eldest brother of the Dalai Lama. He was an incarnate lama from Kumbum Monastery in Qinghai Province who came to Lhasa in $195^{\circ}$ and then went to the United States, where he was a important source of information for the State Department and the CIA.

the name of the three great Gelugpa monasteries around Lhasa: Ganden, Sera, and Drepung. To- 
Tibet Work

Committee

Trijang Rimpoche

Tromo

trungtsi

trungtsigye

trunyichemmo

tsamba

tsendrön

Tsigang

tsipön

Tsondu

Tsuglagang

Wang Qimei

Xikang (Province)

Xi Zhongxun gether these housed about twenty thousand monks in 1959 .

the main Chinese administrative office in Tibet in the 1950s; called "Xizang gongwei" in Chinese

the junior tutor of the Dalai Lama

the Tibetan name for Yadong an acronym that refers to heads of the Ecclesiastic Office (trunyichemmo) and the Revenue Office (tsipön)

an acronym that refers to the four heads of the Ecclesiastic Office (trunyichemmo) and the four heads of the Revenue Office (tsipön). It is constructed from the first syllable of trunyichemmo, the first syllable of tsipön, and the word for "eight." These heads held the most important office apart from the Kashag and often met with the Kashag to discuss important issues. They also chaired the meetings of the Tibetan Assembly.

the title for the heads of the Ecclesiastic Office (Yigtsang)

parched barley flour, the Tibetan staple food monk official aides in the Sectretariat of the Dalai Lama

the Revenue Office

the title for the heads of the Revenue Office the general name for the several levels of assemblies that were sometimes convened by the Kashag to render an opinion on important issues

the main temple in Lhasa that is surrounded by the circular Barkor Road. The Jokhang is located within it. a senior commander and official from the Southwest Bureau. He led the advance troop of the Eighteenth Army Corps to Lhasa in September $195^{1 .}$

the province immediately north of Sichuan, which was predominately ethnic Tibetan (Khamba) in composition. It was merged into Sichuan in 1955 . a senior leader from the Northwest Bureau (vice chairman of the Northwest Military-Administrative Bureau) who was called to Beijing and became the vice premier of the PRC 
Xu Danlu

Yadong

Ya Hanzhang

Zhang Guohua

Zhang Jingwu

Zhou Enlai

Zhu De an important cadre in the Tibet Work Committee. He was the Central Committee's liaison to the Dalai Lama on his trip to and from eastern China in 1954-55.

a town on the border with Sikkim. The place to which the Dalai Lama fled in $195^{0-} 5^{1}$ after the Chinese took military control of Chamdo. In Tibetan it is called Tromo.

a senior Northwest Bureau official in Tibet in the early 195 os

the top Southwest Bureau official in Tibet and the commander of the Eighteenth Army Corps; also the first deputy secretary of the Tibet Work Committee in Lhasa representative of the Central Committtee to the Dalai Lama and first secretary of the Tibet Work Committee the premier of the People's Republic of China the commander in chief of the PLA 


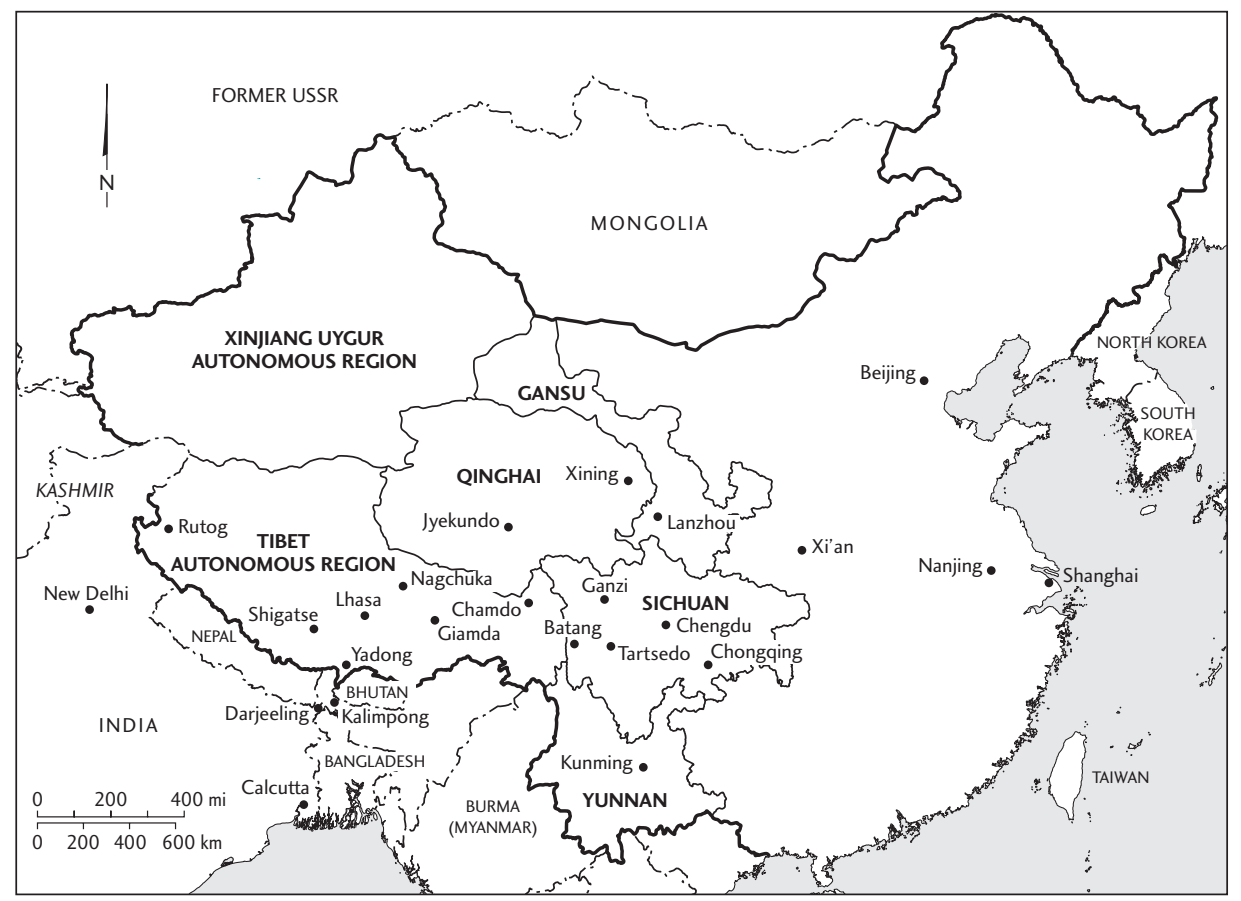

Map 1. China 


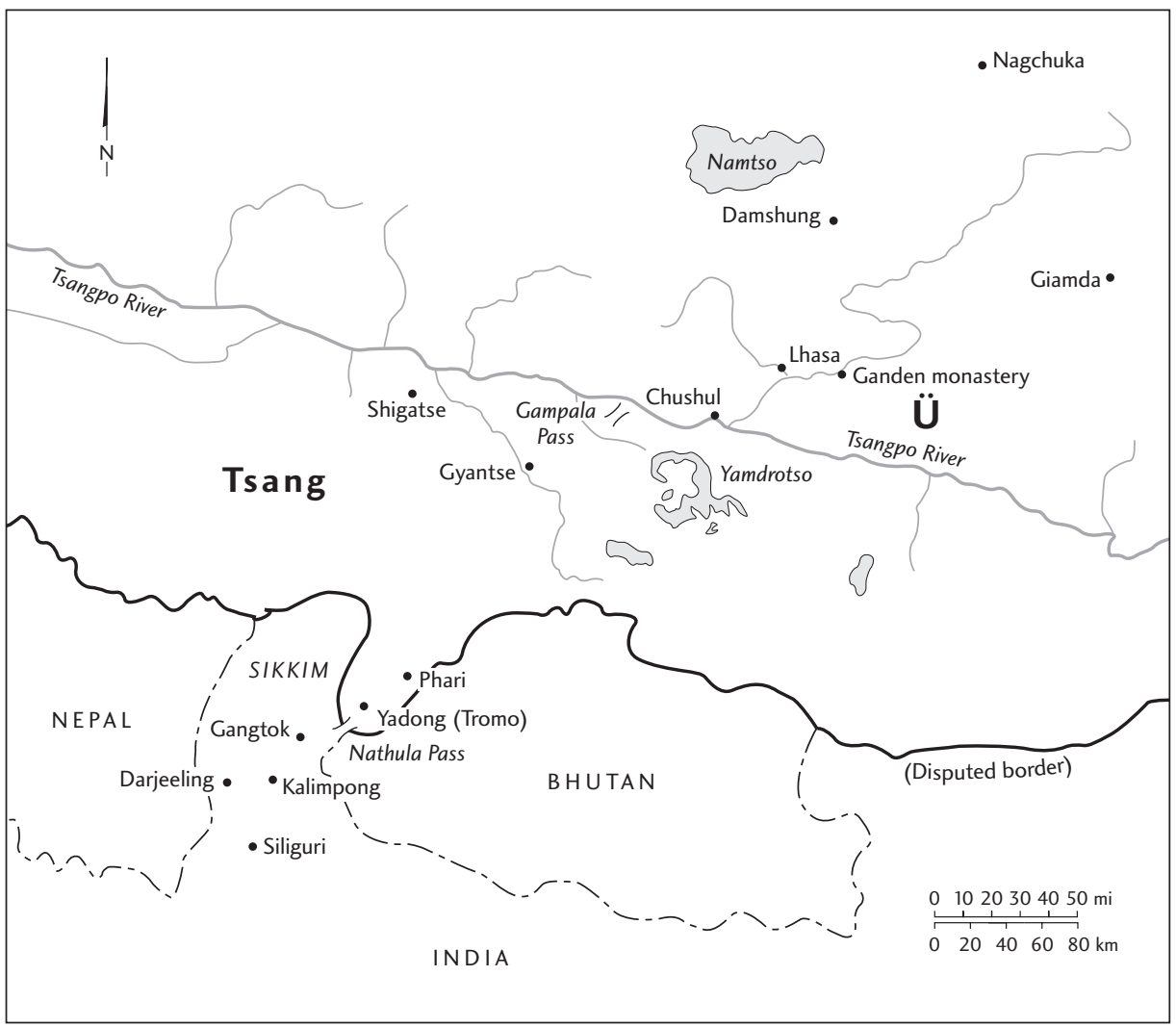

Map 2. Central Tibet 


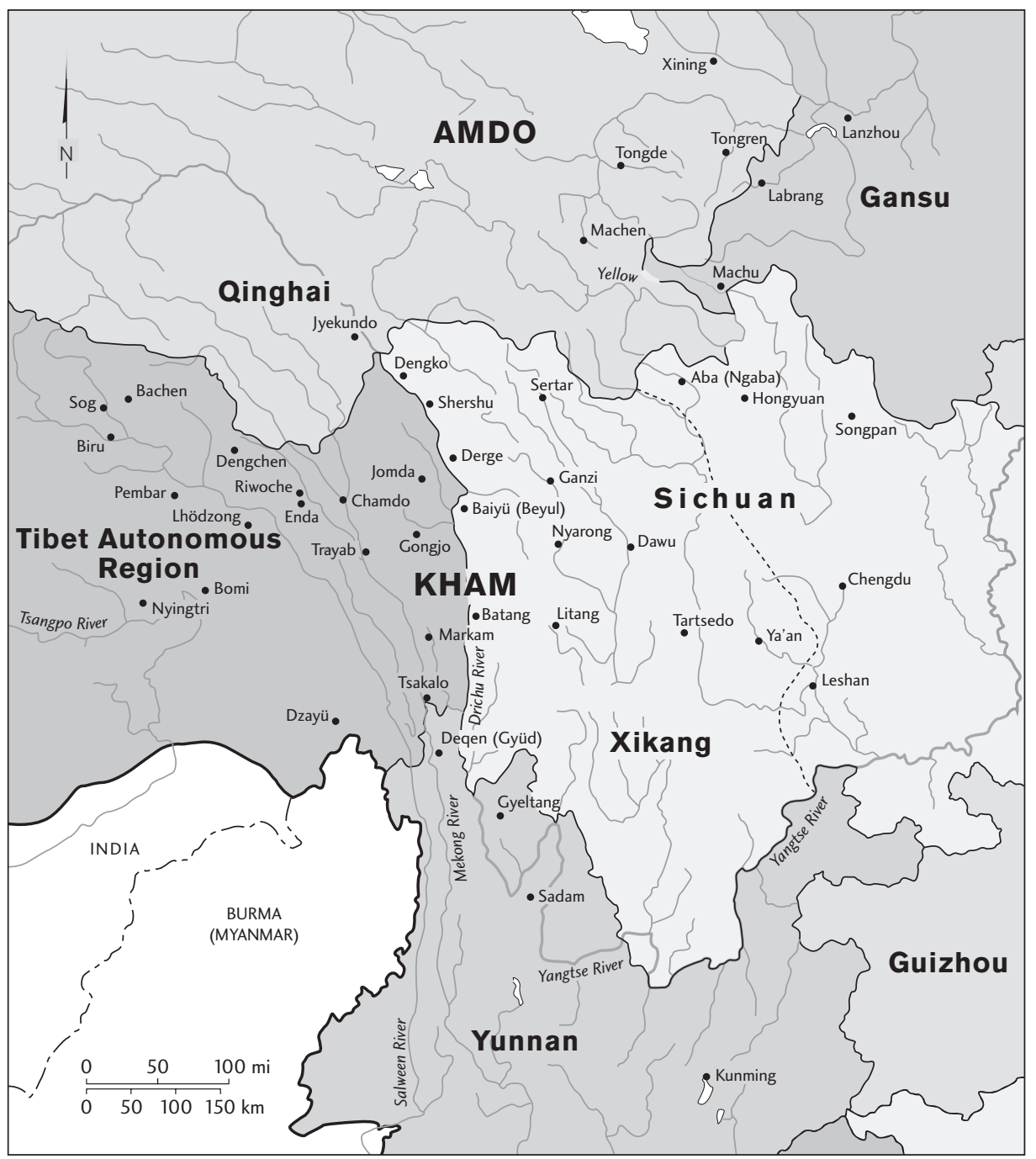

Map 3. Kham 


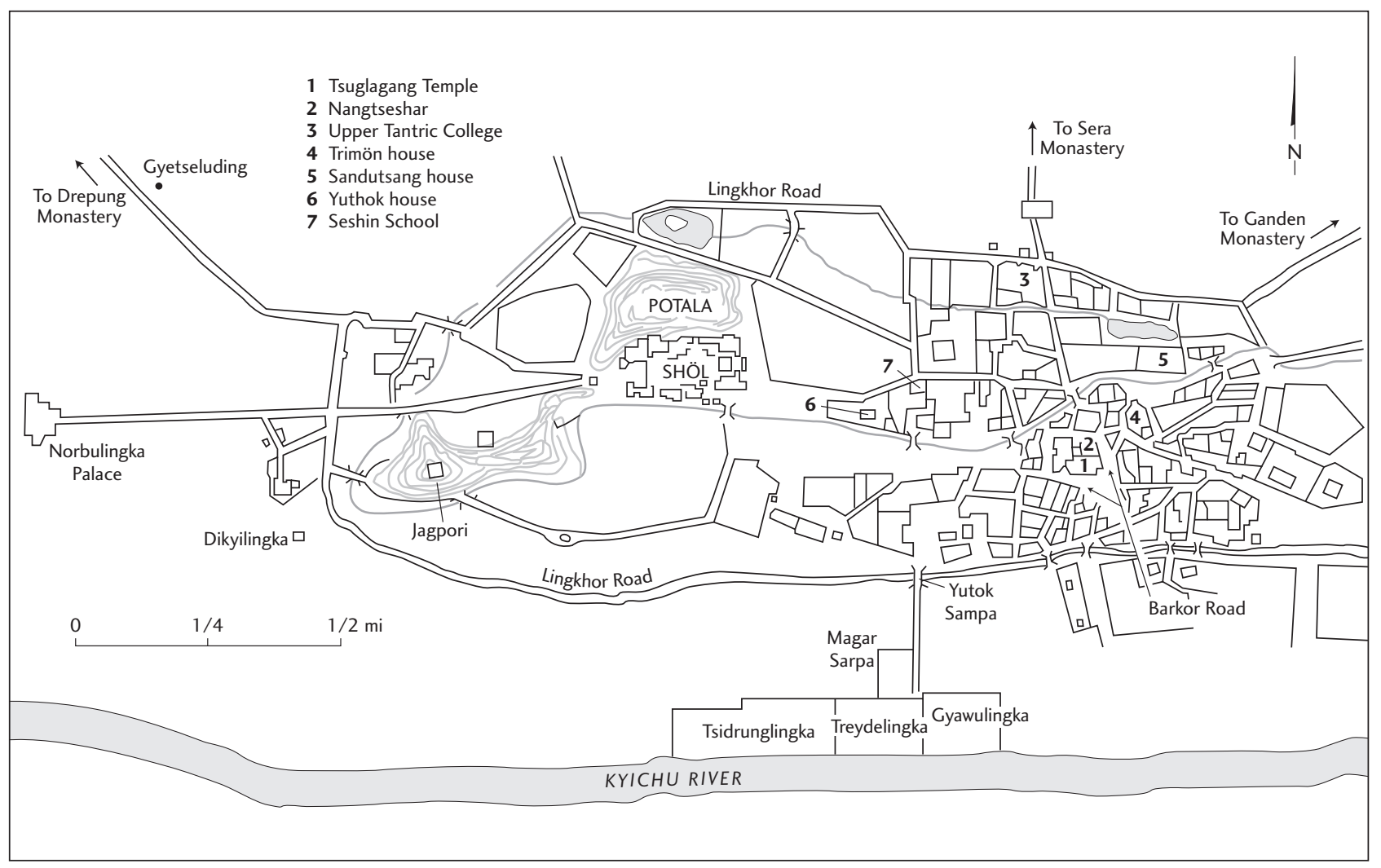

Map 4. Lhasa City, ca. 1950s. Source: adapted from a sketch map by Zasak J. Taring, 1959 (in Nakane 1984). 